\title{
Casein kinase II inhibition induces apoptosis in pancreatic cancer cells
}

\author{
RAINER HAMACHER, DIETER SAUR, RALPH FRITSCH, MAXIMILIAN REICHERT, \\ ROLAND M. SCHMID and GÜNTER SCHNEIDER
}

\begin{abstract}
Second Department of Internal Medicine, Technical University of Munich, Ismaninger Str. 22, D-81675 Munich, Germany
\end{abstract}
Received November 9, 2006; Accepted February 14, 2007

\begin{abstract}
Pancreatic cancer is one of the most common causes of cancer death in western civilization. The five-year survival rate is below $1 \%$ and of the $10 \%$ of patients with resectable disease only around one-fifth survives 5 years. Survival rates have not changed much during the last 20 years, demonstrating the inefficacy of current available therapies. To improve the prognosis of pancreatic cancer, there is the need to develop effective non-surgical treatment for this disease. The protein kinase casein kinase II (CK2) is a ubiquitously expressed serine-threonine kinase and its activity is enhanced in all human tumors examined so far. The contribution of CK2 to the tumor maintenance of pancreatic cancer has not been investigated. To investigate the function of CK2 in pancreatic cancer cells we used the CK2 specific inhibitors 5,6-Dichloro-1- $3-D-$-ribofuranosylbenzimidazole and Apigenin. Furthermore, we interfered with CK2 expression using CK2 specific siRNAs. Interfering with $\mathrm{CK} 2$ function led to a reduction of pancreatic cancer cell viability, which was due to caspase-dependent apoptosis. The induction of apoptosis correlated with a reduced NF-кB-dependent transcriptional activity. This study validates CK2 as a molecular drug target in a preclinical in vitro model of pancreatic cancer.
\end{abstract}

\section{Introduction}

More than 30000 people develop pancreatic adenocarcinoma each year in the United States, and almost all are expected to die from the disease (1). Five-year survival rates stay below $5 \%$ and have not changed much during the last 20 years demonstrating the insufficiency of current therapeutic strategies. Hence, there is the urgent need to characterize new molecular therapeutic strategies in preclinical settings.

Carcinogenesis of ductal pancreatic cancer is mediated by mutations in oncogenes such as $K-R A S$ and tumor suppressor

Correspondence to: Dr Günter Schneider, Second Department of Internal Medicine, Technical University of Munich, Klinikum rechts der Isar, Ismaninger Str. 22, D-81675 Munich, Germany

E-mail: guenter.schneider@1rz.tum.de

Key words: pancreatic cancer, casein kinase II, apoptosis, NF-кB genes such as p16 INK4A, TP53 and MADH4/DPC4/SMAD4 (2). Oncogenes, such as $K-R A S$, activate intrinsic tumor suppressive pathways, such as oncogene-induced apoptosis and oncogeneinduced premature senescence. Therefore a cancer cell has to adopt the ability to conquer intrinsic surveillance programs (3). One consequence is resistance towards apoptosis, an important factor for the survival and drug resistance of cancer cells $(4,5)$. The apoptosis sensing, inducing and executing machinery is regulated at multiple levels. Each level is targeted by apoptosis-resistance mechanisms in pancreatic cancer cells (6). Although pancreatic cancer cells express death receptors such as TNF-R, TRAIL-R and CD95, most resist death-receptor ligand induced apoptosis $(7,8)$. At the mitochondrial level the balance between pro-death and pro-survival members of the BCL-2 protein family decides over resistance towards apoptosis (4). The family member BCL- ${ }_{\mathrm{xL}}$ is overexpressed in pancreatic cancer, suggesting an important role of this pro-survival factor in mediating apoptosis and chemotherapy resistance (9-11).

Casein kinase II (CK2) is a highly conserved serine/ threonine kinase, which is constitutively active and ubiquitously expressed in mammalian cells. Two catalytic subunits CK2 $\alpha$ / CK2 $\alpha$ ' and two regulatory subunits CK2 3 form a tetrameric holoenzyme (12). CK2 phosphorylates more than 300 different substrates and is involved in many aspects of cell biology, such as cell cycle, cell survival or apoptosis $(12,13)$. All human cancers examined so far show an enhanced activity of CK2 $(14,15)$. There is multiple evidence linking CK2 to apoptosis. Thus, phosporylation by CK2 protects proteins from caspasemediated cleavage. CK2 phosphorylated BID, a pro-apoptotic member of the BCL-2 family, restrains caspase-8-mediated cleavage, preventing crosstalk between intrinsic and extrinsic apoptotic signaling (16). CK2 has also direct anti-apoptotic function by phosphorylating and activating the caspase- 8 inhibitory protein ARC (17). Furthermore, the pivotal antiapoptotic transcription factor NF- $\mathrm{BB}$ is activated by $\mathrm{CK} 2$, leading to changes in the expression of pro- and anti-apoptotic genes (18-21). In addition, CK2 increases survivin expression in a $\beta$-catenin-dependent manner (22). Together, this may explain the sensitization towards drug and death-receptor induced apoptosis observed after inhibition of CK2 (23-27).

In this study, we show that the inhibition of CK2 by the specific inhibitors Apigenin and 5,6-Dichloro-1-ß-D-ribofuranosylbenzimidazole (DRB) induces dose-dependent reduction of viability of pancreatic cancer cells, which is due 
to caspase-dependent apoptosis. The specificity of the pharmacological inhibitors was demonstrated with functional genomics using RNA interference. siRNAs directed against CK $2 \alpha$ as well as against CK2 $\alpha^{\prime}$ reduce viability and induce apoptosis. These observations suggest that inhibition of CK2 activity may provide a new strategy for the treatment of pancreatic cancer.

\section{Materials and methods}

Reagents. 5,6-Dichloro-1-ß-D-ribofuranosylbenzimidazole (DRB) (EMD Biosciences, San Diego, CA, USA), Apigenin (EMD Biosciences) and zVAD-fmk (Biomol, Hamburg, Germany) were dissolved in DMSO and stored at $-20^{\circ} \mathrm{C}$.

Cell culture, transfection, siRNAs, plasmid. MiaPaCa2 cells were cultivated in DMEM and DanG cells were cultivated in RPMI supplemented with $10 \%$ fetal calf serum and $1 \%(\mathrm{w} / \mathrm{v})$ penicillin/streptomycin. The pGL3-3хкB-Luc reporter gene construct was recently described (28). Transfections of the reporter gene (500 ng/well) were performed using FuGene6 (Roche Applied Science, Mannheim, Germany) according to the manufacturer's protocol in 12 -well plates. After $24 \mathrm{~h}$ cells were treated with the indicated inhibitors for $6 \mathrm{~h}$. Afterwards cells were incubated in lysis buffer (Promega, Mannheim, Germany) for $15 \mathrm{~min}$, harvested, and cleared by centrifugation for $15 \mathrm{~min}$. Lysates were normalized for protein content. Luciferase activity was determined in an LB 9501 luminometer (Berthold, Bad Wildbad, Germany) using a luciferase assay system (Promega). At least three independent transfection experiments were performed in triplicate. Data are presented as mean and standard error of the mean (SEM). Doublestranded siRNAs were transfected in a concentration of $200 \mathrm{nM}$ using oligofectamine (Invitrogen, Karlsruhe, Germany) according to the manufacturer's protocol. Fifty thousand cells/well were transfected in a 6-well plate, 2000 cells/well were transfected in a 96-well plate. The sequence for the control siRNA was 5'-AACAGUCGCGUUUGCGACUGG-3', the target sequences of the CK2 specific siRNAs (sense strand) were CK $2 \alpha+411$ 5'-AAGCAGGGCCAGAGUUUACAC-3'; CK $2 \alpha^{\prime}+49$ 5'-AACAGUCUGAGGAGCCGCGAG-3'. siRNAs were purchased from Ambion, Austin, TX, USA and were stored in a $20-\mu \mathrm{M}$ stock at $-80^{\circ} \mathrm{C}$.

Preparation of total cell lysates. Whole-cell lysates were prepared by incubating cell pellets for $30 \mathrm{~min}$ at $4^{\circ} \mathrm{C}$ in immunoprecipitation buffer (50 mM HEPES, $150 \mathrm{mM} \mathrm{NaCl}, 1 \mathrm{mM}$ EDTA, $0.5 \%$ NP-40, 10\% glycerol, $1 \mathrm{mM}$ dithiothreitol, $1 \mathrm{mM}$ phenylmethysulfonylfluoride and $5 \mathrm{mM} \mathrm{NaF}$ ). Insoluble material was removed by centrifugation and lysates were aliquoted and stored at $-80^{\circ} \mathrm{C}$.

Viability assay. Viability of the cells was measured using MTT-assay according to the manufacturer's protocol (Roche Applied Science). Five thousands cells/well were grown for the indicated time periods under the indicated treatment conditions. After the incubation period MTT was added to a final concentration of $0.5 \mathrm{mg} / \mathrm{ml}$. After $4 \mathrm{~h}$ the formed formazan crystals were solubilized with the solubilization solution over night. The spectrophotometrical absorbance was measured using an ELISA reader (Anthos 2001, Anthos
Microsystems, Cologne, Germany) at a wavelength of $600 \mathrm{nM}$. As a reference wavelength $650 \mathrm{nM}$ was used. All experiments were performed three times as a triplicate and presented as mean and standard error of the mean (SEM).

Western blot analysis. Extracts were normalized for protein and heated at $95^{\circ} \mathrm{C}$ for 5 min in Lämmli buffer. Proteins were resolved on $10 \%$ SDS-polyacrylamide gels and electrophoretically transferred to polyvinylidene difluoride membranes (Millipore, MA, USA) in a semi-dry blotting system. Membranes were blocked in phosphate-buffered saline (PBS) supplemented with 5\% skim-milk and $0.1 \%$ NP-40, and incubated with antibodies against CK2, PARP (BD Pharmingen, San Diego, CA, USA), BCL- ${ }_{\mathrm{XL}}$ (Cell Signal Technology, Beverly, MA, USA) and B-actin (Sigma-Aldrich, Munich, Germany) for $1 \mathrm{~h}$ at room temperature. Proteins recognized by the antibodies were detected by the Odyssey Infrared Imaging System (Licor, Bad Homburg, Germany) using Alexa680-coupled (Molecular Probes, Leiden, Netherland) or IRDeye800-coupled (Rockland, Gilbertsville, PA, USA) secondary antibodies.

Apoptosis-stain. Chromatin was stained with Hoechst 33342 $(4 \mu \mathrm{M})$ and typical apoptotic morphological changes were visualized using fluorescence microscopy. The apoptotic fractions of 300 cells were counted per individual experiment. All experiments were performed three times as triplicate and presented as mean and standard error of the mean (SEM).

Statistical methods. All data were obtained from at least three independent experiments performed in duplicate, and the results are presented as mean and standard error of the mean (SEM). To demonstrate statistical significance Student's t-test was used. P-values are indicated in the figure legends.

\section{Results}

The CK2 specific inhibitors 5,6-Dichloro-1- $\beta$-D-ribofuranosylbenzimidazole $(D R B)$ and Apigenin reduce viability of pancreatic cancer cells. To investigate the influence of CK2 on tumor maintenance of pancreatic cancer cells, we treated MiaPaCa2 and DanG cells with the specific chemical CK2 inhibitors 5,6-Dichloro-1-ß-D-ribofuranosylbenzimidazole (DRB) and Apigenin. Viability of cells was measured after treatment with increasing doses of the inhibitors over a time course of $48 \mathrm{~h}$ using MTT assays. In MiaPaCa2 cells, the viability was dose-dependently decreased to 51 and $31 \%$ of controls after 24 and $48 \mathrm{~h}$ of treatment with the highest concentration DRB (200 $\mu \mathrm{M})$ used (Fig. 1A, upper graph). With Apigenin $(150 \mu \mathrm{M})$ at the highest concentration the viability of $\mathrm{MiaPaCa} 2$ cells was reduced to 45 and $33 \%$ of controls after 24 and $48 \mathrm{~h}$ of treatment (Fig. 1A, lower graph). In DanG cells the viability was dose-dependently reduced to $48 \%$ of controls after $24 \mathrm{~h}$ and $22 \%$ of controls after $48 \mathrm{~h}$ of treatment with the highest concentration DRB $(200 \mu \mathrm{M})$ used (Fig. 1B, upper graph). Apigenin $(150 \mu \mathrm{M})$ reduced the viability of DanG cells to $55 \%$ of controls after $24 \mathrm{~h}$ and to $27 \%$ of controls after $48 \mathrm{~h}$ of treatment (Fig. 1B, lower graph). These data suggest that CK2 maintains viability of pancreatic cancer cells. 
A)

MiaPaCa2
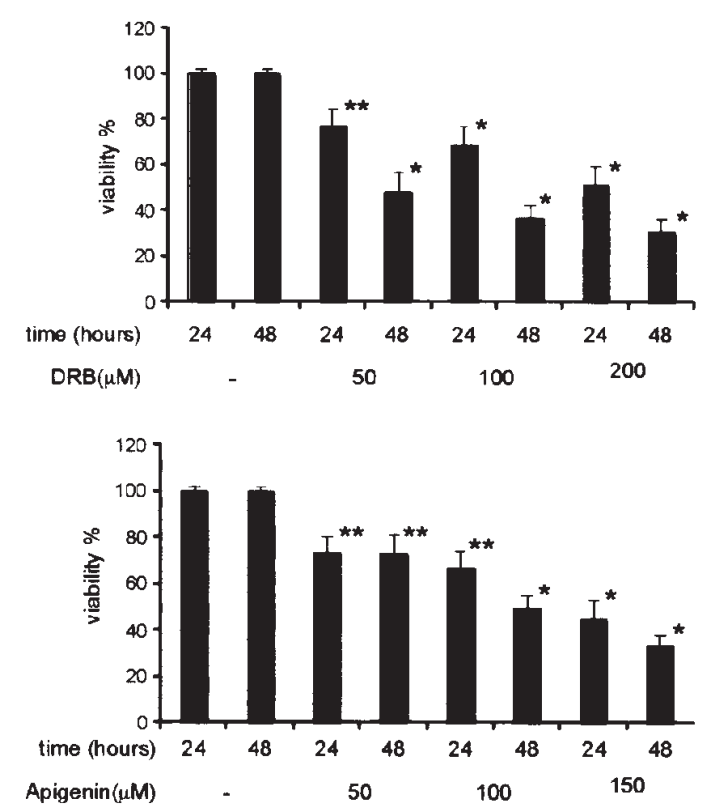

B)
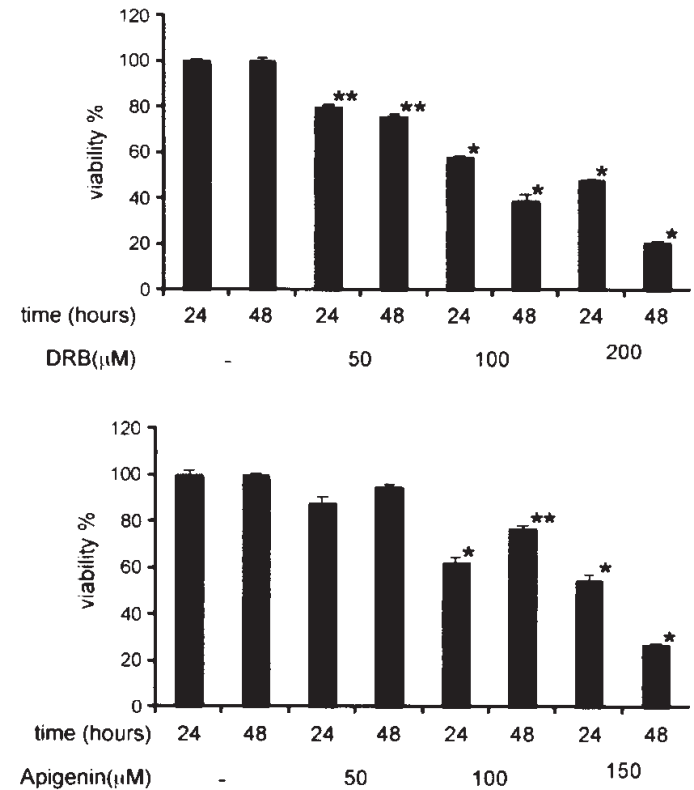

Figure 1. CK2 inhibition reduces viability of pancreatic cancer cells. (A) MiaPaCa2 cells were treated with 50, 100 and $200 \mu \mathrm{M}$ DRB (upper graph) or with 50, 100 and $150 \mu \mathrm{M}$ Apigenin (lower graph). After 24 and $48 \mathrm{~h} \mathrm{MTT}$ assays were performed (Student's t-test, ${ }^{*} \mathrm{p}<0.001$ versus controls; ${ }^{* *} \mathrm{p}<0.05 \mathrm{versus}$ control). (B) DanG cells were treated with 50, 100 and $200 \mu \mathrm{M}$ DRB (upper graph) or with 50, 100 and $150 \mu \mathrm{M}$ Apigenin (lower graph). After 24 and $48 \mathrm{~h}$ MTT assays were performed (Student's t-test, ${ }^{*} \mathrm{p}<0.001$ versus controls; ${ }^{* *} \mathrm{p}<0.05$ versus control).

Reduced viability after the inhibition of CK2 is due to caspasedependent apoptosis in pancreatic cancer cells. To investigate the cause of the reduced viability of pancreatic cancer cells we looked for apoptotic changes after the inhibition of CK2. As shown in Fig. 2A, chromatin condensation, a hallmark of apoptosis, was detected in DRB (Fig. 2A, upper row, middle) and Apigenin (Fig. 2A, lower row, left) treated MiaPaCa2 cells after staining the chromatin with Hoechst dye, which was absent in cells treated with vehicle alone (Fig. 2A, upper row, left). DRB-induced apoptotic changes as well as Apigenininduced apoptotic changes were prevented by the pan-caspase inhibitor zVAD-fmk (Fig. 2A, upper row, right and lower row, right). Next we quantified the apoptotic changes of DRB- or Apigenin-treated MiaPaCa2 cells. DRB and Apigenin induced a dose-dependent increase of the apoptotic fraction. Thirtyfive percent of the cells were apoptotic after $24 \mathrm{~h}$ of treatment with DRB $(200 \mu \mathrm{M})$ (Fig. 2B, left upper graph) and 55\% of the cells were apoptotic after $48 \mathrm{~h}$ of treatment with DRB (Fig. 2B, left lower graph). Simultaneous treatment with DRB and $\mathrm{zVAD}$-fmk $(3.6 \%$ after $24 \mathrm{~h}$ and $5.4 \%$ after $48 \mathrm{~h}$ ) reduced the apoptotic fraction to control levels $(1.7 \%$ after $24 \mathrm{~h}$ and $3.5 \%$ after $48 \mathrm{~h}$ ). Apigenin also induced apoptosis of MiaPaCa2 cells in a dose-dependent fashion. After $24 \mathrm{~h}$ of treatment with $150 \mu \mathrm{M}$ Apigenin, $48 \%$ of the cells were apoptotic reaching $71 \%$ after 48 h (Fig. 2B, right upper and lower graph). Again, the apoptotic fraction after the treatment with Apigenin was significantly reduced by zVAD-fmk cotreatment to $12 \%$ after $24 \mathrm{~h}$ and $18 \%$ after $48 \mathrm{~h}$ (Fig. 2B). Also, we found a dose-dependent increase in PARP cleavage $24 \mathrm{~h}$ after the treatment of MiaPaCa2 with DRB and Apigenin (Fig. 2C). DRB- as well as Apigenin-induced PARP cleavage was completely inhibited by zVAD-fmk (Fig. 2C).
These data demonstrate that inhibition of CK2 by DRB and Apigenin induced caspase-dependent apoptosis in $\mathrm{MiaPaCa} 2$ cells.

Kinetics of apoptosis after CK2 inhibition. To investigate the kinetics of apoptosis induction after treatment with CK2 inhibitors in more detail, we determined PARP cleavage over time. In DRB-treated $\mathrm{MiaPaCa} 2$ cells, the cleavage product of PARP was detected $6 \mathrm{~h}$ after the treatment with $200 \mu \mathrm{M}$ DRB further increasing over time (Fig. 3A). Similarly, Apigenininduced PARP cleavage was seen 6-8 h after treatment and further increased over the investigated time period (Fig. 3B). These data suggest an early onset of apoptosis induction by CK2 inhibition. One major anti-apoptotic principle activated by $\mathrm{CK} 2$ is the transcription factor NF-KB (18-20). To determine the contribution of NF- $\mathrm{KB}$ to the observed apoptotic phenotype we measured $\mathrm{NF}-\kappa \mathrm{B}$-dependent transcriptional activity using luciferase reporter gene assays in MiaPaCa2 cells $6 \mathrm{~h}$ after treatment. At this time-point we detected a dose-dependent definite reduction of NF- $\mathrm{BB}$-dependent transcriptional activity after treatment with DRB (Fig. 3C) and Apigenin (Fig. 3D). With the highest concentration used the activity was reduced to $33 \%$ (DRB) and 9\% (Apigenin) of controls, respectively. These data suggest an early-onset apoptosis induction by CK2 inhibition. Furthermore, the activity of the anti-apoptotic transcription factor $\mathrm{NF}-\mathrm{\kappa B}$ was reduced by $\mathrm{CK} 2$ inhibition.

CK2 inhibitors induce apoptosis independent of $B C L-_{X L}$ regulation. It was shown that $\mathrm{DRB}$ and Apigenin reduce the expression of the anti-apoptotic BCL-2 family member BCL- ${ }^{-}$ (24). To investigate the contribution of $\mathrm{BCL}_{-\mathrm{XL}}$ to the observed apoptotic phenotype after CK2 inhibition in MiaPaCa2 cells 
A)
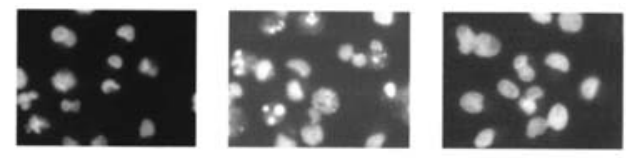

untreated

24 h DRB

24 h DRB + zVAD-fmk
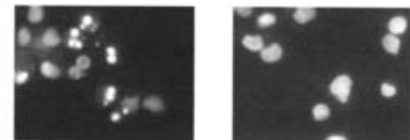

$24 \mathrm{~h}$ Apigenin $24 \mathrm{~h}$ Apigenin + zVAD-fmk

B)
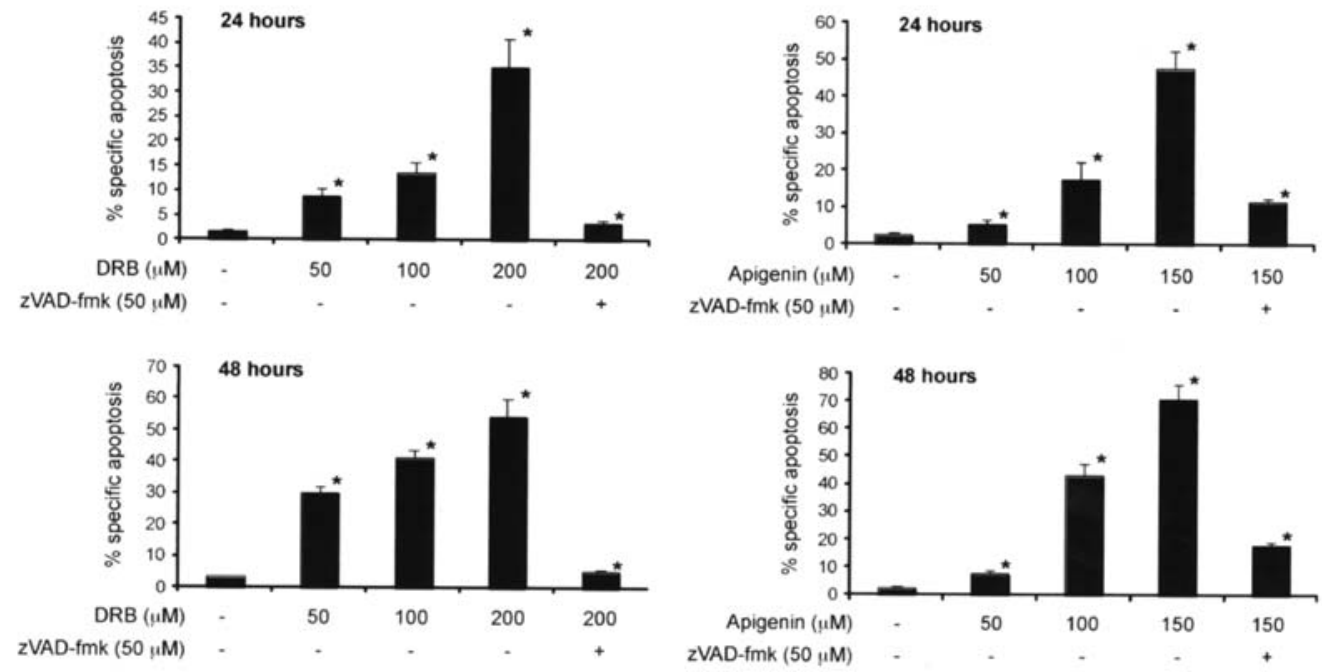

C)

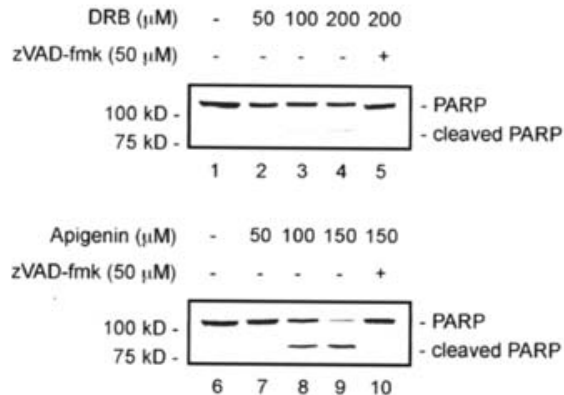

Figure 2. CK2 inhibition induces apoptosis of pancreatic cancer cells. (A) Photomicrographs (original magnification, $\mathrm{x} 40$ ) of MiaPaCa2 cells after the staining of the nuclei with Hoechst. Cells were treated for $24 \mathrm{~h}$ with vehicle (upper row, left), $200 \mu \mathrm{M}$ DRB (upper row, middle), $200 \mu \mathrm{M} \mathrm{DRB}$ and $50 \mu \mathrm{M} \mathrm{zVAD-fmk}$ (upper row, right), $150 \mu \mathrm{M}$ Apigenin (lower row, left) or $150 \mu \mathrm{M}$ Apigenin and $50 \mu \mathrm{M}$ zVAD-fmk (lower row, right). (B) Quantification of apoptotic cells $24 \mathrm{~h}$ (upper graphs) and $48 \mathrm{~h}$ (lower graphs) by fluorescence microscopy after Hoechst stain. MiaPaCa2 cells were treated with indicated doses of DRB (left graphs) or Apigenin (right graphs). To demonstrate caspase dependency cells were co-treated with $50 \mu \mathrm{M}$ zVAD-fmk at the highest concentration DRB and Apigenin used (Student's t-test, ${ }^{*} \mathrm{p}<0.001$ versus controls). (C) PARP Western blot of DRB (upper Western blot) or Apigenin (lower Western blot) treated MiaPaCa2 cells. Increasing concentration of DRB and Apigenin were used as indicated. In lane 5 and $10 \mathrm{MiaPaCa} 2$ cells were co-treated with $50 \mu \mathrm{M} \mathrm{zVAD-fmk.}$

we analyzed $\mathrm{BCL}-\mathrm{xL}$ expression by Western blotting. As demonstrated in Fig. 4A, a significant reduction of BCL-xL protein abundance was not observed over a time period of $24 \mathrm{~h}$ after the treatment with DRB. Also, no definite reduction of $\mathrm{BCL}_{\mathrm{xL}}$ protein expression was detected after the treatment with Apigenin over a time period of $24 \mathrm{~h}$ in $\mathrm{MiaPaCa} 2$ cells (Fig. 4B). These data argue for a $\mathrm{BCL}-\mathrm{xL}^{-}$-independent pathway of apoptosis after the inhibition of $\mathrm{CK} 2$ in pancreatic cancer cells.

Knock-down of the catalytical CK2 subunits reduces viability and induces apoptosis of MiaPaCa2 cells. To control the specificity of the effects observed after the treatment with the chemical inhibitors of CK2, we used RNA interference technology. Therefore we transfected $\mathrm{MiaPaCa} 2$ cells with siRNAs directed against CK2 $\alpha^{\prime}$ and CK2 $\alpha$. As demonstrated in Fig. 5A, the transfection of the siRNAs against CK2 $\alpha^{\prime}$ led to a reduction of CK2 $\alpha^{\prime}$ protein abundance below $10 \%$ compared to control siRNA transfected or untransfected MiaPaCa2 cells $48 \mathrm{~h}$ after transfection. Furthermore, CK2 $\alpha$ expression was not changed in CK2 $\alpha^{\prime}$ siRNA transfected cells. Transfection of the CK $2 \alpha$ siRNA led to reduction of CK2 $\alpha$ expression to $22 \%$ compared to untransfected or control siRNA transfected cells (Fig. 5A). Again, no change of the CK2 $\alpha^{\prime}$ expression was detected after the transfection of the CK2 $\alpha$ siRNA. Next we investigated the effects after the knock-down of the catalytical CK2 subunits 
A)

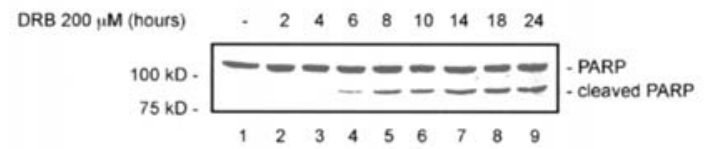

C)

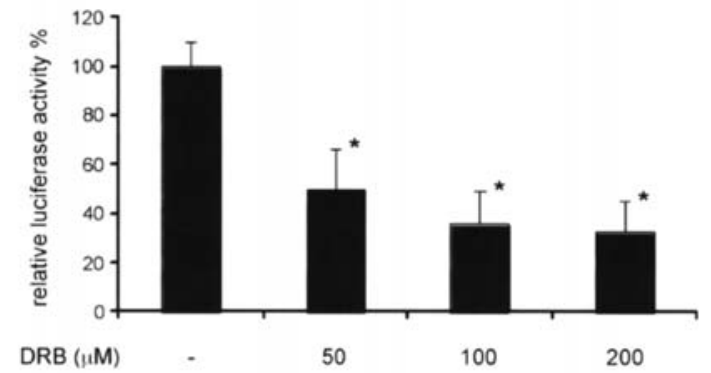

B)

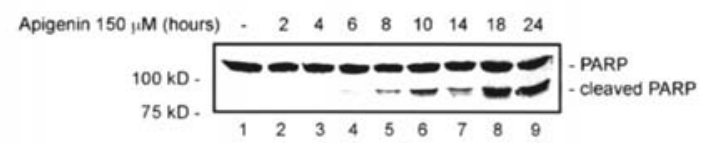

D)

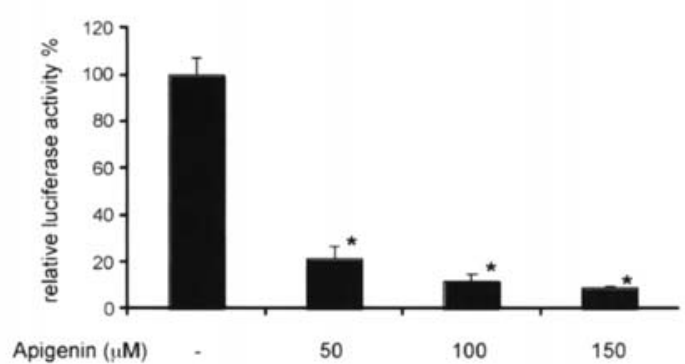

Figure 3. Kinetics of apoptosis after CK2 inhibition and NF-кB reporter gene assay. (A) MiaPaCa2 cells were treated with $200 \mu \mathrm{M}$ DRB over time and onset of apoptosis was determined by PARP Western blotting. The PARP cleavage product is indicated. (B) MiaPaCa2 cells were treated with $150 \mu \mathrm{M}$ Apigenin over time and onset of apoptosis was determined by PARP Western blotting. The PARP cleavage product is indicated. (C) MiaPaCa2 cells were transfected with $500 \mathrm{ng}$ pGL3-3хкB-Luc luciferase reporter gene construct. Twenty-four hours after the transfection the cells were treated with DRB as indicated. Six hours after the treatment $\mathrm{NF}-\kappa \mathrm{B}$ transcriptional activity was measured (Student's t-test, ${ }^{*} \mathrm{p}<0.001$ versus controls). (D) MiaPaCa2 cells were transfected with $500 \mathrm{ng}$ pGL3-3хкB-Luc luciferase reporter gene construct. Twenty-four hours after the transfection the cells were treated with Apigenin as indicated. Six hours after the treatment NF- $\mathrm{BB}$ transcriptional activity was measured (Student's t-test, ${ }^{*} \mathrm{p}<0.001$ versus controls).

A)

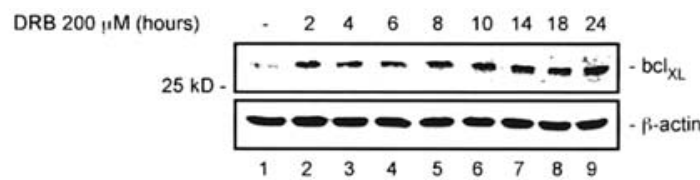

B)

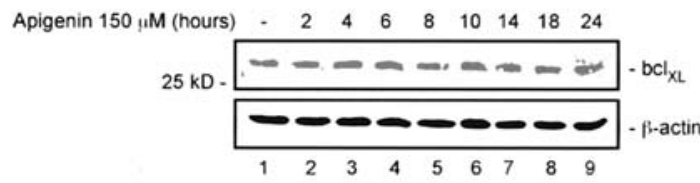

Figure 4. Apoptosis after the inhibition of CK2 is independent of BCL- $\mathrm{XL}$ protein expression. (A) MiaPaCa2 cells were treated with $200 \mu \mathrm{M}$ DRB and $\mathrm{BCL}^{-} \mathrm{xL}$ protein expression was monitored over a time course of $24 \mathrm{~h}$ using Western blotting. (B) MiaPaCa2 cells were treated with $150 \mu \mathrm{M}$ Apigenin and $\mathrm{BCL}_{-\mathrm{xL}}$ protein expression was monitored over a time course of $24 \mathrm{~h}$ using Western blotting.

over time on MiaPaCa2 cell viability. In control siRNA transfected MiaPaCa2 cells no significant change of viability was detected (Fig. 5B). Transfection of the CK2 $\alpha^{\prime}$ siRNA reduced the viability of $\mathrm{MiaPaCa} 2$ cells to 73,63 and $45 \%$ of controls 24, 48 and $96 \mathrm{~h}$ after the transfection, respectively (Fig. 5B). The knock-down of the CK2 $\alpha$ subunit also reduced viability of MiaPaCa2 cells. Here, a reduction of viability to 90,68 and $51 \%$ compared to untransfected controls 48, 72 and $96 \mathrm{~h}$ after the transfection was detected.

To investigate whether the observed reduction of viability after the knock-down of the catalytical CK2 subunits is due to apoptosis we counted the apoptotic fraction after staining the cells with Hoechst. Whereas the fraction of apoptotic cells remained below 5\% in control siRNA and untransfected $\mathrm{MiaPaCa} 2$ cells over a time period of $96 \mathrm{~h}$, definite apoptosis was induced by the CK2 knock-down (Fig. 5C). After the transfection of the CK2 $\alpha^{\prime}$ siRNA 10,25 and $28 \%$ apoptotic cells were detected 48, 72 and $96 \mathrm{~h}$ after the transfection, respectively (Fig. 5C). In CK2 $\alpha$ siRNA transfected cells 10,
18 and $31 \%$ apoptotic cells were detected 48, 72 and $96 \mathrm{~h}$ after the transfection, respectively (Fig. 5C). In accordance, we found PARP cleavage after the transfection of the siRNAs against the catalytical CK2 subunits $96 \mathrm{~h}$ after the transfection (Fig. 5D).

The reduced viability after the knock-down of the catalytical CK2 subunits and the detection of apoptosis validates the results obtained with the chemical inhibitors and further supports the notion that CK2 contributes to the survival of pancreatic cancer cells.

\section{Discussion}

CK2 is essential for survival in many cellular systems $(23,29-31)$. This prompted us to investigate the influence of CK2 towards the viability of pancreatic cancer cells. Our studies showed that the viability of pancreatic cancer cells depends on CK2 activity, since the pharmacological inhibition, as well as RNA interference approach led to a definite reduction of viable cells. Furthermore, we demonstrated that apoptosis is a major mechanism leading to the observed reduction of viability after the inhibition of CK2. In addition, the apoptotic phenotype correlated with a reduced activity of the transcription factor NF-кB. Therefore, our pre-clinical model defines CK2 as a potential drug target for future therapies of pancreatic cancer. This is in line with a recent observation, finding CK2 in a siRNA screen for survival kinases in pancreatic cancer cells (32).

Interfering with CK2 activity induces apoptosis or confers susceptibility towards chemotherapeutic or death-receptor mediated apoptosis (24-27,33-35). Furthermore, inhibition of CK2 by antisense oligonucleotide strategies induced apoptosis in a xenograft model of prostate cancer (36). Even though, apoptosis after the inhibition of CK2 is a common cellular response, the molecular mechanisms are not entirely clear. In the mammary cancer cell line Hs578 the anti-apoptotic BCL-2 family member $\mathrm{BCL}_{-\mathrm{XL}}$ has been shown to be regulated by 
B)

C)

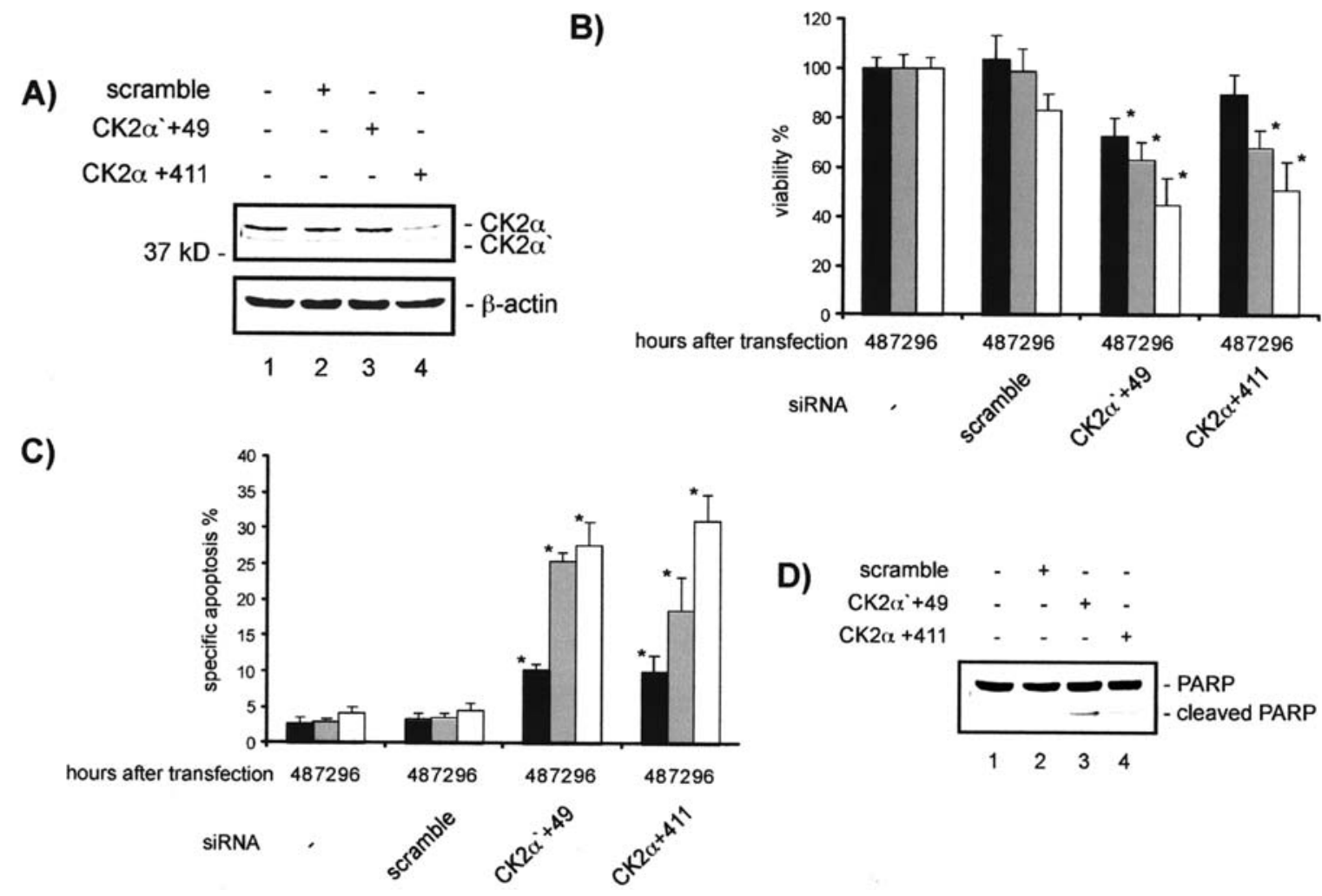

Figure 5. Knock-down of the catalytical CK2 subunits CK2 $\alpha^{\prime}$ and CK2 $\alpha$ reduces the viability and induces apoptosis of MiaPaCa2 cells. (A) Western blot analysis of CK2 $\alpha$ and CK2 $\alpha^{\prime} 48$ h after the transfection of MiaPaCa2 cells with a scramble control siRNA (lane 2), a CK2 $\alpha^{\prime}$ siRNA (lane 3) and a CK2 $\alpha$ siRNA (lane 4) compared to untransfected control cells (lane 1). 3 -actin controls equal protein loading. (B) MTT assay of MiaPaCa2 cells 48,72 and $96 \mathrm{~h}$ after the transfection of a scramble control siRNA, a CK2 $\alpha^{\prime}$ siRNA and a CK2 $\alpha$ siRNA compared to untransfected control cells (Student's t-test, ${ }^{*}$ p $<0.001$ versus controls). (C) Quantification of apoptotic cells 48, 72 and $96 \mathrm{~h}$ after the transfection of a scramble control siRNA, CK2 $\alpha$ ' and CK2 $\alpha$ siRNAs compared to untransfected control cells by fluorescence microscopy after Hoechst stain (Student's t-test, ${ }^{*}$ p $<0.001$ versus controls). (D) PARP Western blot of CK2 $\alpha$ and $\mathrm{CK} 2 \alpha^{\prime}$ transfected MiaPaCa2 cells. MiaPaCa2 cells were transfected with the indicated siRNAs. Ninety-six hours after the transfection extracts were prepared and PARP cleavage was detected by Western blots.

CK2 (24). Although we found a rapid and distinct decrease of $\mathrm{NF}-\kappa \mathrm{B}$ transcriptional activity after the treatment of $\mathrm{MiaPaCa} 2$ cells with the CK2 inhibitors used and $\mathrm{BCL}_{-\mathrm{XL}}$ is an $\mathrm{NF}_{-\kappa \mathrm{B}}$ target gene, we detected no decrease of $\mathrm{BCL}_{-\mathrm{xL}}$ protein abundance, suggesting BCL- ${ }_{\mathrm{xL}}$-independent apoptosis. Since it was demonstrated that in pancreatic cancer cell lines inhibition of NF- $\mathrm{KB}$ activity enhances the sensitivity of cells towards chemotherapeutic agents as well as death receptormediated apoptosis and since the observed inhibition of NF- $\mathrm{KB}$ activity after the treatment with $\mathrm{CK} 2$ inhibitors parallels the onset of apoptosis, NF-кB seems to lower the apoptotic threshold in our cellular model $(37,40)$. The molecular mechanism of NF- $\mathrm{KB}$ regulation observed after the inhibition

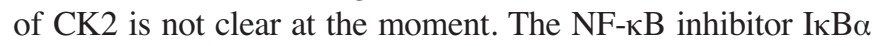
was shown to be destabilized by CK2-dependent phosphorylation in its C-terminal PEST domain $(19,21)$. We observed a reduction of $\mathrm{I} \kappa \mathrm{B} \alpha$ expression after the inhibition of CK2 in MiaPaCa2 cells, suggesting an I $\mathrm{B} \alpha \alpha$-independent pathway of NF- $\kappa \mathrm{B}$ inhibition in our model (data not shown). Whether a direct phosphorylation of RelA/p65 at Ser-529 by CK2, shown to contribute to NF- $\kappa \mathrm{B}$ activation after TNF- $\alpha$ signaling contributes to NF- $\mathrm{KB}$ activity in pancreatic cancer cells awaits further investigation $(26,41)$.

The molecular mechanism of apoptosis initiation after inhibition of CK2 in pancreatic cancer cells is unclear. Interestingly, a recent report demonstrated phosphorylation of pro-caspase-2 at Ser-157 by CK2. Dephosphorylated procaspase-2 after CK2 inhibition is activated by dimerization and cleaves pro-caspase-8 (42). In accordance, we found cleavage of pro-caspase- 8 after the inhibition of CK2 in MiaPaCa2 cells (data not shown). Therefore, CK2 might act in two ways to induce apoptosis in pancreatic cancer cells. On the one hand, CK2 inhibition lowers the anti-apoptotic threshold via NF- $\mathrm{KB}$. On the other hand, the caspase-2/8 pathway activated after CK2 inhibition leads to BID cleavage, whereas BID is more susceptible to caspase- 8 cleavage after lack of CK2 phosphorylation.

In summary, our studies demonstrate the requirement of CK2 for survival of pancreatic cancer cells. Interfering with CK2 activity might be a novel approach for pancreatic cancer therapies.

\section{Acknowledgements}

We thank Birgit Kohnke-Ertel and Konstanze Geiger for excellent technical support. This study was funded by the Dr Ing. Leonhard-Lorenz-Stiftung (to G.S.).

\section{References}

1. Jemal A, Tiwari RC, Murray T, Ghafoor A, Samuels A, Ward E, Feuer EJ and Thun MJ: Cancer Statistics, 2004. CA Cancer J Clin 54: 8-29, 2004. 
2. Schneider G, Siveke JT, Eckel F and Schmid RM: Pancreatic cancer: basic and clinical aspects. Gastroenterology 128: $1606-1625,2005$

3. Lowe SW, Cepero E and Evan G: Intrinsic tumour suppression. Nature 432: 307-315, 2004.

4. Igney FH and Krammer PH: Death and anti-death: tumour resistance to apoptosis. Nat Rev Cancer 2: 277-288, 2002.

5. Schulze-Bergkamen $\mathrm{H}$ and Krammer PH: Apoptosis in cancerimplications for therapy. Semin Oncol 31: 90-119, 2004.

6. Gukovskaya AS and Pandol SJ: Cell death pathways in pancreatitis and pancreatic cancer. Pancreatology 4: 567-586, 2004.

7. Kornmann M, Ishiwata T, Kleeff J, Beger HG and Korc M: Fas and Fas-ligand expression in human pancreatic cancer. Ann Surg 231: 368-379, 2000 .

8. Ibrahim SM, Ringel J, Schmidt C, Ringel B, Muller P, Koczan D, Thiesen HJ and Lohr M: Pancreatic adenocarcinoma cell lines show variable susceptibility to trail-mediated cell death. Pancreas 23: 72-79, 2001.

9. Hinz S, Trauzold A, Boenicke L, Sandberg C, Beckmann S Bayer E, Walczak $\mathrm{H}$, Kalthoff $\mathrm{H}$ and Ungefroren $\mathrm{H}$ : Bcl-Xl protects pancreatic adenocarcinoma cells against Cd95- and trail-receptor-mediated apoptosis. Oncogene 19: 5477-5486, 2000.

10. Evans JD, Cornford PA, Dodson A, Greenhalf W, Foster CS and Neoptolemos JP: Detailed tissue expression of Bcl-2, Bax, $\mathrm{Bak}$ and $\mathrm{Bcl}-\mathrm{X}$ in the normal human pancreas and in chronic pancreatitis, ampullary and pancreatic ductal adenocarcinomas. Pancreatology 1: 254-262, 2001

11. Campani D, Esposito I, Boggi U, Cecchetti D, Menicagli M, De Negri F, Colizzi L, Del Chiaro M, Mosca F, Fornaciari G and Bevilacqua G: Bcl-2 expression in pancreas development and pancreatic cancer progression. J Pathol 194: 444-450, 2001.

12. Litchfield DW: Protein kinase Ck2: structure, regulation and role in cellular decisions of life and death. Biochem J 369: 1-15, 2003.

13. Meggio F and Pinna LA: One-thousand-and-one substrates of protein kinase Ck2? FASEB J 17: 349-368, 2003.

14. Guerra B and Issinger OG: Protein kinase $\mathrm{Ck} 2$ and its role in cellular proliferation, development and pathology. Electrophoresis 20: 391-408, 1999

15. Tawfic S, Yu S, Wang H, Faust R, Davis A and Ahmed K: Protein kinase Ck2 signal in neoplasia. Histol Histopathol 16: 573-582, 2001

16. Desagher S, Osen-Sand A, Montessuit S, Magnenat E, Vilbois F, Hochmann A, Journot L, Antonsson B and Martinou JC: Phosphorylation of bid by casein kinases I and II regulates its cleavage by caspase 8 . Mol Cell 8: 601-611, 2001.

17. Li PF, Li J, Muller EC, Otto A, Dietz R and von Harsdorf R: Phosphorylation by protein kinase Ck2: a signaling switch for the caspase-inhibiting protein arc. Mol Cell 10: 247-258, 2002.

18. Romieu-Mourez R, Landesman-Bollag E, Seldin DC, Traish AM, Mercurio F and Sonenshein GE: Roles of Ikk kinases and protein kinase $\mathrm{Ck} 2$ in activation of nuclear factor-kappab in breast cancer. Cancer Res 61: 3810-3818, 2001.

19. Shen J, Channavajhala P, Seldin DC and Sonenshein GE: Phosphorylation by the protein kinase $\mathrm{Ck} 2$ promotes calpain-mediated degradation of Ikappabalpha. J Immunol 167: 4919-4925, 2001.

20. Romieu-Mourez R, Landesman-Bollag E, Seldin DC and Sonenshein GE: Protein kinase Ck2 promotes aberrant activation of nuclear factor-kappab, transformed phenotype, and survival of breast cancer cells. Cancer Res 62: 6770-6778, 2002.

21. Kato T Jr, Delhase M, Hoffmann A and Karin M: Ck2 is a Cterminal Ikappab kinase responsible for NF-kappab activation during the UV response. Mol Cell 12: 829-839, 2003.

22. Tapia JC, Torres VA, Rodriguez DA, Leyton L and Quest AF: Casein kinase $2(\mathrm{Ck} 2)$ increases survivin expression via enhanced beta-catenin- $\mathrm{T}$ cell factor/lymphoid enhancer binding factordependent transcription. Proc Natl Acad Sci USA 103: 15079-15084, 2006

23. Guo C, Yu S, Davis AT, Wang H, Green JE and Ahmed K: A potential role of nuclear matrix-associated protein kinase $\mathrm{Ck} 2$ in protection against drug-induced apoptosis in cancer cells. J Biol Chem 276: 5992-5999, 2001.

24. Ravi R and Bedi A: Sensitization of tumor cells to Apo2 ligand/ trail-induced apoptosis by inhibition of casein kinase II. Cancer Res 62: 4180-4185, 2002.
25. Izeradjene K, Douglas L, Delaney A and Houghton JA: Influence of casein kinase II in tumor necrosis factor-related apoptosisinducing ligand-induced apoptosis in human rhabdomyosarcoma cells. Clin Cancer Res 10: 6650-6660, 2004

26. Farah M, Parhar K, Moussavi M, Eivemark S and Salh B: 5,6Dichloro-ribofuranosylbenzimidazole- and Apigenin-induced sensitization of colon cancer cells to Tnf-alpha-mediated apoptosis. Am J Physiol Gastrointest Liver Physiol 285: G919-G928, 2003

27. Izeradjene K, Douglas L, Delaney A and Houghton JA: Casein kinase II (Ck2) enhances death-inducing signaling complex (Disc) activity in trail-induced apoptosis in human colon carcinoma cell lines. Oncogene 24: 2050-2058, 2005.

28. Haussler U, von Wichert G, Schmid RM, Keller F and Schneider G: Epidermal growth factor activates nuclear Factorkappab in human proximal tubule cells. Am J Physiol Renal Physiol 289: F808-F815, 2005.

29. Padmanabha R, Chen-Wu JL, Hanna DE and Glover CV: Isolation, sequencing and disruption of the yeast $\mathrm{Cka} 2$ gene: casein kinase II is essential for viability in saccharomyces cerevisiae. Mol Cell Biol 10: 4089-4099, 1990.

30. Ahmed K, Gerber DA and Cochet C: Joining the cell surviva squad: an emerging role for protein kinase Ck2. Trends Cell Biol 12: 226-230, 2002 .

31. Buchou T, Vernet M, Blond O, Jensen HH, Pointu H, Olsen BB, Cochet $\mathrm{C}$, Issinger OG and Boldyreff $\mathrm{B}$ : Disruption of the regulatory beta subunit of protein kinase $\mathrm{Ck} 2$ in mice leads to a cell-autonomous defect and early embryonic lethality. Mol Cell Biol 23: 908-915, 2003

32. Giroux V, Iovanna J and Dagorn JC: Probing the human kinome for kinases involved in pancreatic cancer cell survival and gemcitabine resistance. FASEB J 20: 1982-1991, 2006.

33. Ruzzene M, Penzo D and Pinna LA: Protein kinase $\mathrm{Ck} 2$ inhibitor 4,5,6,7-tetrabromobenzotriazole (Tbb) induces apoptosis and caspase-dependent degradation of haematopoietic lineage cell-specific protein 1 (Hs1) in jurkat cells. Biochem J 364: 41-47, 2002.

34. Faust RA, Tawfic S, Davis AT, Bubash LA and Ahmed K Antisense oligonucleotides against protein kinase Ck2-alpha inhibit growth of squamous cell carcinoma of the head and neck in vitro. Head Neck 22: 341-346, 2000.

35. Yang BF, Xiao C, Roa WH, Krammer PH and Hao C: Calcium/ calmodulin-dependent protein kinase II regulation of C-Flip expression and phosphorylation in modulation of Fas-mediated signaling in malignant glioma cells. J Biol Chem 278: 7043-7050, 2003

36. Slaton JW, Unger GM, Sloper DT, Davis AT and Ahmed K: Induction of apoptosis by antisense $\mathrm{Ck} 2$ in human prostate cancer xenograft model. Mol Cancer Res 2: 712-721, 2004.

37. Arlt A, Vorndamm J, Breitenbroich M, Folsch UR, Kalthoff $\mathrm{H}$, Schmidt WE and Schafer H: Inhibition of Nf-kappab sensitizes human pancreatic carcinoma cells to apoptosis induced by etoposide (Vp16) or doxorubicin. Oncogene 20: 859-868, 2001

38. Thomas RP, Farrow BJ, Kim S, May MJ, Hellmich MR an Evers BM: Selective targeting of the nuclear factor-kappab pathway enhances tumor necrosis factor-related apoptosisinducing ligand-mediated pancreatic cancer cell death. Surgery 132: $127-134,2002$

39. Muerkoster S, Arlt A, Witt M, Gehrz A, Haye S, March C Grohmann F, Wegehenkel K, Kalthoff H, Folsch UR and Schafer H: Usage of the Nf-kappab inhibitor sulfasalazine as sensitizing agent in combined chemotherapy of pancreatic cancer. Int J Cancer 104: 469-476, 2003

40. Sato T, Odagiri H, Ikenaga SK, Maruyama M and Sasaki M: Chemosensitivity of human pancreatic carcinoma cells is enhanced by Ikappabalpha super-repressor. Cancer Sci 94: 467-472, 2003.

41. Wang D, Westerheide SD, Hanson JL and Baldwin AS Jr: Tumor necrosis factor alpha-induced phosphorylation of Rela/ P65 on Ser529 is controlled by casein kinase II. J Biol Chem 275: 32592-32597, 2000

42. Shin S, Lee Y, Kim W, Ko H, Choi H and Kim K: Caspase-2 primes cancer cells for trail-mediated apoptosis by processing procaspase-8. EMBO J 24: 3532-3542, 2005. 